\title{
Primary retention of permanent lower first molar: case report and twelve-year
}

\section{follow-up}

Retenção primária de primeiro molar inferior permanente: relato de caso e acompanhamento de 12 anos

Retención primaria primero menor molar permenent: informe de casos y seguimiento de 12 años

Received: 03/09/2021 | Reviewed: 03/26/2021 |Accept: 03/28/2021 | Published: 04/09/2021

\author{
Ana Paula Farnezi Bassi \\ ORCID: https://orcid.org/0000-0002-0031-4953 \\ Araçatuba School of Dentistry, Brazil \\ E-mail: ana.bassi@unesp.br \\ Karen Rawen Tonini \\ ORCID: https://orcid.org/0000-0001-7061-3986 \\ Araçatuba School of Dentistry, Brazil \\ E-mail: karenraawen@gmail.com \\ Daniela Ponzoni \\ ORCID: https://orcid.org/0000-0001-5928-0914 \\ Araçatuba School of Dentistry, Brazil \\ E-mail: daniela.ponzoni@unesp.br
}

\begin{abstract}
Impaction of permanent first and second molars is an uncommon condition, with a prevalence rate of $0.01 \%$ to $0.08 \%$ and few cases are described in the literature. Many etiological factors are reported for failure in the eruption of these teeth. However, the mechanisms responsible for this occurrence are still unknown. This article describes the treatment of a 12-year-old patient with a permanent lower molar impacted with twelve-year follow-up. The presence of the impacted tooth was diagnosed from an asymptomatic extra-oral volumetric increase at the base of the patient's jaw. The first impacted molar was surgically removed by intraoral access under local anesthesia. The patient was not able to follow orthodontic follow-up. In 12-year follow-up, it was observed that the removal of the impacted tooth was the best option for the case. This article also offers a discussion to broaden the understanding of the causes and treatment options in cases of permanent molar impacted.
\end{abstract}

Keywords: Tooth eruption; Impacted tooth; Primary retention.

\section{Resumo}

Impacção de primeiros e segundos molars permanentes é uma condição incomum, com índice de prevalência de $0,01 \%$ a $0.08 \%$ e poucos casos são descritos na literatura. Muitos fatores etiológicos são relatados para falha na erupção destes dentes. Contudo, os mecanismos responsáveis por esta ocorrência ainda são desconhecidos. Este artigo descreve o tratamento de um paciente de 12 anos de idade portador de um molar inferior permanente impactado com acompanhamento de doze anos. A presença do dente impactado foi diagnosticada a partir de um aumento volumétrico extra-oral assintomático na base da mandíbula do paciente. O primeiro molar impactado foi removido cirurgicamente por acesso intra-bucal sob anestesia local. O paciente não teve condições de acompanhamento ortodôntico. Em acompanhamento de 12 anos, observou-se que a remoção do dente impactado foi a melhor opção para o caso. Este artigo também oferece uma discussão para ampliar a compreensão das causas e opções de tratamento nos casos de impacção de molare spermanentes.

Palavras-chave: Erupção dentaria; Dente impactado; Retenção primária.

\section{Resumen}

El impacto de los molars permanentes primero y segundo es una condición poco frecuente, con una tasa de prevalencia de $0,01 \%$ a $0,08 \%$ y pocos casos se describenen la literatura. Muchos factores etiológicos se divulgan para la falla en la erupción de estos dientes. Sin embargo, aún se desconocen los mecanismos responsables de esta ocurrencia. Este artículo describe el tratamiento de un paciente de 12 años con un molar inferior permanente impactado con seguimiento de doce años. La presencia del diente impactado fue diagnosticada a partir de un aumento volumétrico extra-oral asintomático en la base de la mandíbula del paciente. El primer molar impactado fue extirpado quirúrgicamente por acceso intraoral bajo anestesia local. El paciente no pudo seguir el seguimiento de la ortodoncia. En seguimiento de 12 años, se observó que la eliminación del diente impactado era la major opción para el caso. Este 
artículo también ofrece un debate para ampliar la comprensión de las causas y las opciones de tratamiento en los casos de molar permanente impactado.

Palabras clave: Erupción dental; Diente impactado; Retención primaria.

\section{Introduction}

The tooth eruption process regards the continuous axial or occlusal movement of a tooth beginning from its embryonic position in the maxilla or mandible until reaching its functional position in the dental arch (Marks et al., 1996). Physiological eruption is defined as the time at which $2 / 3$ to $3 / 4$ of the length of the root is developed. The tooth eruption mechanism can be perturbed by local or systemic factors (Almonaitiene et al., 2010; Proof et al., 2006). Impaction is defined as advanced or complete root growth without eruption (Almonaitiene et al., 2010; Marks et al., 1996).

Tooth eruption can be hindered by adjacent teeth, a dense bone lining, excess soft tissue or an inadequate length of the dental arch (Peterson et al., 2005). Impacted teeth remain partially or completely retained in the interior of the bone (De Freitas et al., 2008; Marzola et al., 1988; Peterson et al., 2005). Impaction is categorized as either primary or secondary. Primary retention is the interruption of the eruption process of a normally located tooth that has developed prior to its emergence in the arch and without the involvement of a physical barrier. Secondary retention is the interruption of the eruption process after the emergence of the tooth and without the involvement of a physical barrier or abnormal position of the tooth, resulting in infra oclusion (Raghoebar et al., 1989, 1991). In the literature, this eruption disorder is also denominated ankylosis, submersion or reimpaction (Zengin et al., 2008).

Primary impaction of deciduous teeth is considered rare (Raghoebar et al., 1989, 1991; Zengin et al., 2008), whereas secondary impaction occurs more frequently in deciduous teeth and more rarely in permanent molars (Biederman et al., 1962; McCartney et al., 1974). The deciduous lower second molar is affected more often than the lower first molar, followed by the deciduous upper first and second molars (Biederman et al., 1962). In the permanent dentition, cases of impaction most frequently involve the lower third molars, followed by upper third molars, upper canines and lower premolars (Peterson et al., 2005). Impaction of upper premolars, lower canines and incisors is uncommon (Grover et al., 1985). With the exception of third molars, which have a high incidence of impaction, the upper and lower first and second molars are rarely impacted, ${ }^{4,13,14}$ with a prevalence rate ranging from $0.01 \%$ to $0.08 \%$ (Bereket et al., 2011; Dachi et al., 1961; Grover et al., 1985; Valmaseda-Castellón et al., 1999).

In a study involving the radiographic evaluation of 5000 individuals, 4825 had one or more impacted teeth, but no cases of impacted lower first molars were found (Grover et al., 1985). In another study involving the evaluation of 1218 impacted teeth in 684 individuals, only three cases of impacted lower first molars and eight cases of impacted lower second molars were found (Dachi et al., 1961). A retrospective analysis of 104,408 individuals in Turkey reports a prevalence rate of 200 impacted lower first and second molars in 170 patients: $168(0.16 \%)$ second molars [81 $(0.07 \%)$ in the maxillary arch and $87(0.08 \%)$ in the mandibular arch] and $32(0.03 \%)$ first molars [17 $(0.01 \%)$ in the maxillary arch and $15(0.01 \%)$ in the mandibular arch] (Bereket et al., 2011).

The likely cause of a missing permanent lower first molar in a child or young adult is previous extraction or, more rarely, impaction (Mellor et al., 1981), which may be caused by primary or, more rarely, secondary retention (Chintakanon et al., 1998; Oliver et al., 1986; Raghoebar et al 1989, 1991). Recent studies on the emergence of the teeth report a strong correlation between the eruption process and innervation pattern (Bang et al., 2005; Becktor et al., 2002; Fujiyama et al., 2004; Parner et al., 2001). One study found that denervation of the inferior alveolar nerve resulted in a reduction in the distribution of the epithelial cell rests of Malassez, which preceded the development of ankylosis and impaction (Fujiyama et al., 2004). Changes in the eruption process of the permanent lower first molar may be due to a local innervation disturbance, such as a viral infection in the nerve or other tissues (Bang et al., 2005; Becktor et al., 2002). In a radiographic study involving 29 
patients with impacted permanent lower first molars, delayed maturation in the affected tooth occurred in 17 patients and cases of crown enlargement, dilacerated roots and follicle thickening were found; eruption occurred in 10 individuals, whereas the impacted molar in eight patients was surgically removed (Nielsen et al., 2006).

In some situations, it is extremely difficult to suggest an obvious cause that explains the occurrence of an impacted permanent lower first molar. However, in a study involving six cases, retention was associated with a pathological process in three cases. In the other cases, the impacted molar exhibited incomplete root formation positioned mesially toward the root of the second molar. In two cases, vertical impaction had occurred, with the presence of curved, completely formed roots and normal follicle (as determined by the histopathological exam). Three cases exhibited accentuated curvature of the root apices, which were in closely contact with the lower edge of the mandible (Mellor et al., 1981).

Ectopic eruption should be considered a possible cause of permanent first molar retention. In such cases, premature resorption occurs of the distal root surface of the deciduous second molar, leading to the formation of a cavity on this surface sufficient to become an obstacle to the eruption of the first molar (Bjerklin et al., 1993; Da Silva Filho et al., 1996; Kurol et al., 1982; Pomarico et al., 2006). It has also been suggested that the premature loss of the deciduous second molar increases the likelihood of failed eruption of the permanent first molar, which becomes compacted by the permanent second molar and premolar, characterizing a persistent mechanical obstacle to the initial eruption pathway (Watkins et al., 1977).

Impacted molars can cause problems with chewing performance and the stability of the dental arch. Treatment options include surgical repositioning (autotransplantation) (Andreasen et al., 1990; Bedoya et al., 2009; Frank et al., 2000; McAboy et al., 2003; Park et al., 2010; Sabuncuoglu et al., 2010; Schatz et al., 1994; Schwartz et al., 1985), surgical exposure followed by orthodontic traction (Anderson et al., 2012; Frank et al., 2000; Going et al., 1999; Kokich et al., 1993; McAboy et al., 2003; Sabuncuoglu et al., 2010; Sawicka et al., 2007) or extraction (Babacan et al., 2006; Frank et al., 2000; Going et al., 1999; Kokich et al., 1993; McAboy et al., 2003; Ohaman et al., 1980; Sawicka et al; 2007).

This paper describes a case of an impacted permanent lower first molar for which surgical removal was the treatment of choice.

\section{Case Report}

A 12-year-old male Caucasian patient sought dental care at the School of Dentistry of the Universidade Paulista in the city of Araçatuba, state of São Paulo, Brazil, with the complaint of an increase in volume on the right side of the face. The patient history revealed no trauma to the area, medication use or systemic problems. The patient signed the medical record in which he authorizes the publication of his clinical data and images for scientific purposes.

The extraoral clinical exam revealed facial asymmetry caused by an increase in volume at the base of the mandible on the right side (Figure 1). Skin coloration was normal, with no observation of hyperemia or hyperthermia in the corresponding area. The patient reported slow evolution and the absence of symptoms. The affected area had a hardened aspect upon palpation. The intraoral exam revealed the absence of teeth 46 and 47 (Figure 2). The radiographic exam revealed that teeth 46 and 47 had not yet erupted. Tooth 46 was in a vertical position at the base of the mandible and tooth 47 was in a normal eruption position (Figure 3). The increase in extra-oral volume was caused by the camber of the mandible cortical bone due to the impacted tooth 46 . Following surgical-orthodontic analysis, the decision was made to extract tooth 46 base on the impossibility of orthodontic traction due to the deep position of the tooth in the base of the mandible. 
Figure 1 - Clinical aspect demonstrating increased volume in mandibular region on right side (arrow).

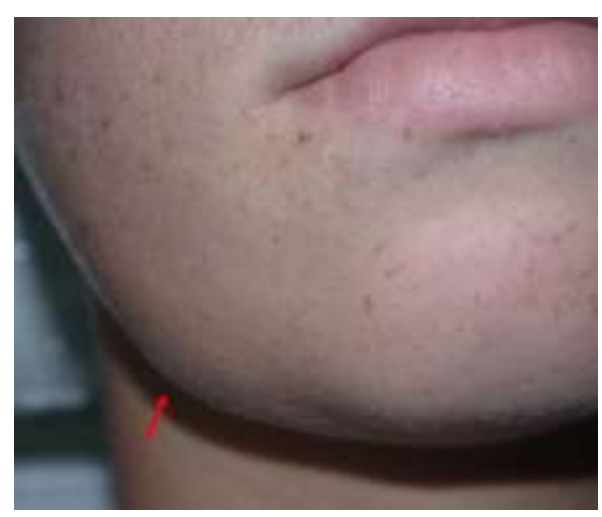

Source: Authors.

Figure 2 - Clinical aspect revealing absence of teeth 46 and 47.

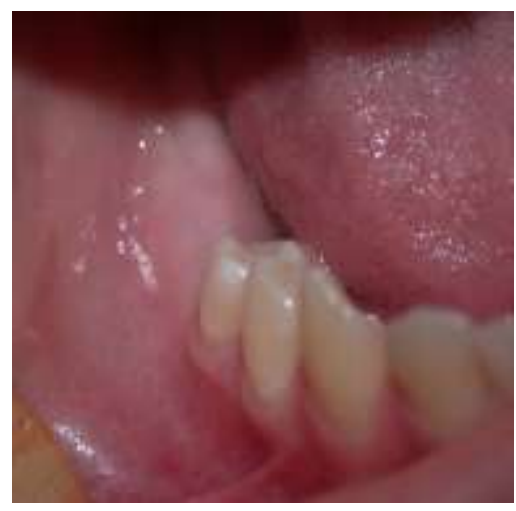

Source: Authors.

Figure 3 - Radiograph revealing unerupted teeth 46 and 47.

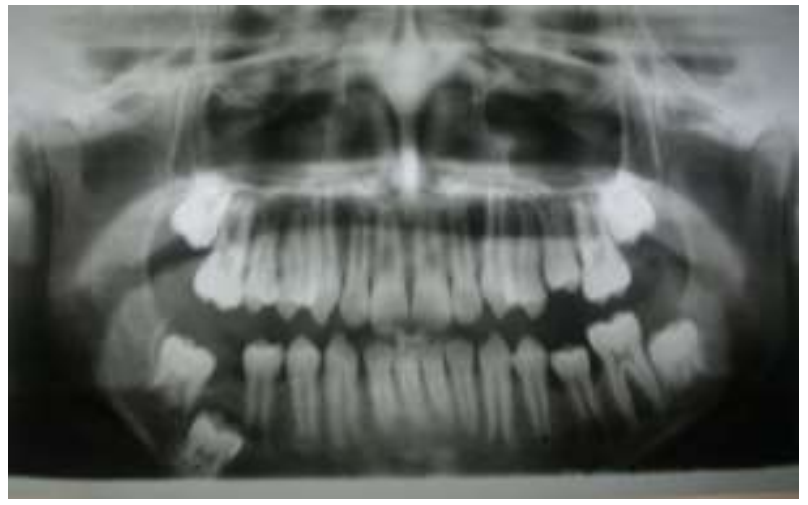

Source: Authors.

Since the patient proved cooperative, the surgical plan involved an intraoral approach under local anesthesia. Local anesthesia was performed with mepivacaine $2 \%$ and adrenalin $(1: 100,000)$ for the regional block of the inferior alveolar, lingual and buccal nerves. A linear incision was made in the fundus of the vestibular sulcus in the region of tooth 43 to the ascending ramus of the mandible on two planes (superficial mucous membrane and deep muscle) until reaching the periosteum. After folding back the mucoperiosteal flap to the base of the mandible, osteotomy of the vestibular facet was performed with a low-speed 702 surgical bit for the localization of the impacted tooth (Figure 4). The tooth was sectioned 
vertically in two parts. It was discovered that the four roots ( 2 mesial and 2 distal) were lodged in the base of the mandible and needed to be separated for the complete removal of the tooth. Following its removal, it was observed that the tooth had been in close contact with the mandibular canal. The nerve bundle was exposed, but intact (Figure5). The flap was repositioned and sutured on two planes: the internal muscle plane (polyglactin 910 no. 5 thread) and a superficial plane (4.0 silk thread) (Figure $6)$.

Figure 4 - Surgical localization of impacted tooth.

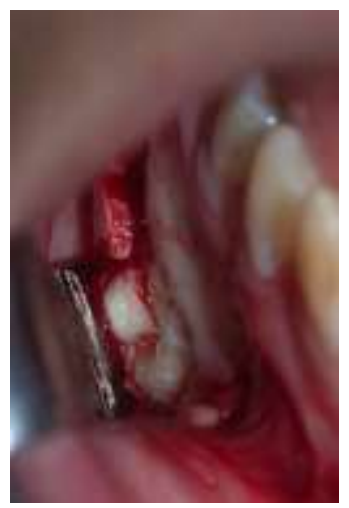

Source: Authors.

Figure 5 - Post-extraction: A - Close contact between tooth and mandibular canal and maintenance of vasculonerve bundle; B - impacted tooth with 2 mesial and 2 distal roots with accentuated curvature.
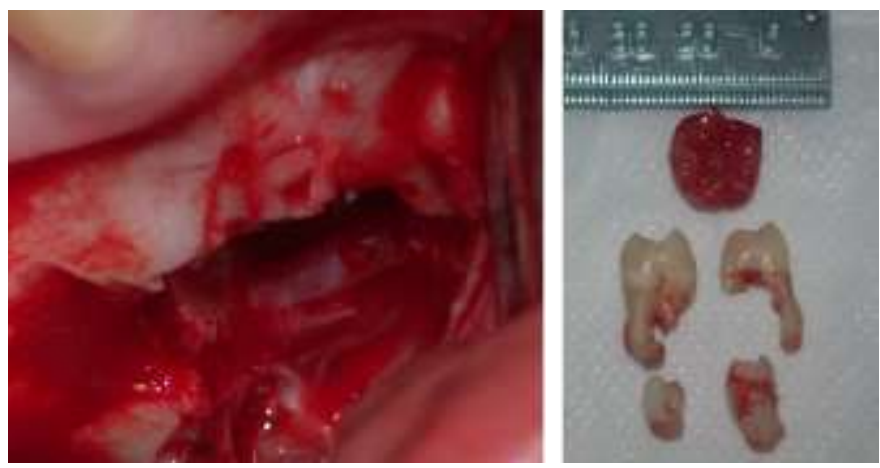

Source: Authors.

Figure 6 - Immediate postoperative period.

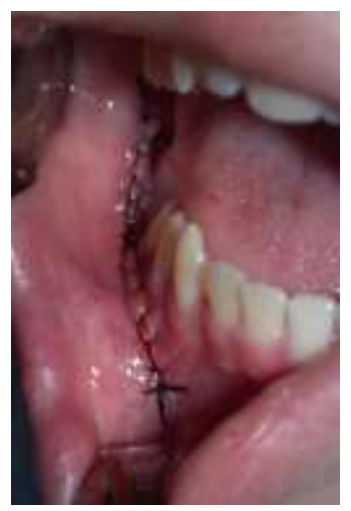

Source: Authors. 
The patient was medicated with an antibiotic (amoxicillin $500 \mathrm{mg}$, every 8 hours for 7 days), an anti-inflammatory (nimesulide $₫ 100 \mathrm{mg}$, every 12 hours for 3 days), an analgesic (Tylenol® $750 \mathrm{mg}$, every six hours as needed) and topical chlorhexidine $0.12 \%$ for seven days. The patient was instructed to restrict himself to a diet of liquids and pasty foods and avoid trauma to the mandible (Figure 7). The superficial suture was removed on Day 7 of the postoperative period. Satisfactory healing was observed, with the absence of paresthesia. Regarding the extra-oral camber, remodeling of the base of the mandible occurred throughout follow up, with the return of the normal shape.

Figure 7 - Radiographic exam in immediate postoperative period.

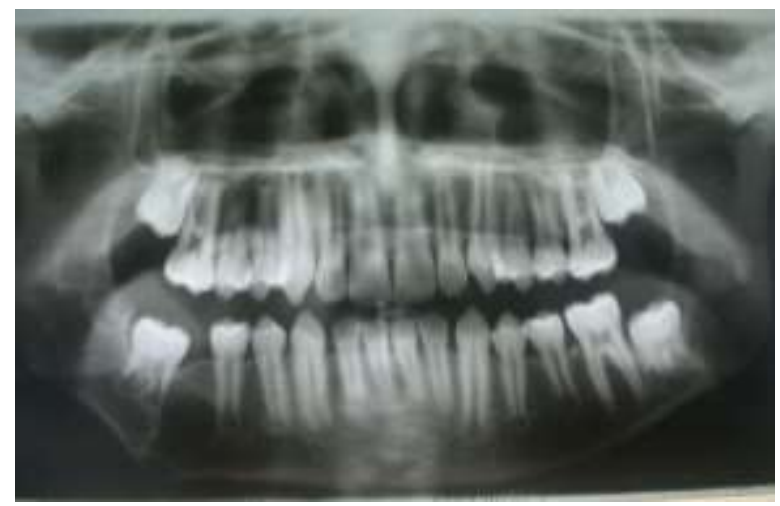

Source: Authors.

Twelve years later, we observed the natural repositioning of the second and third lower molars in place of the first molar lost and the satisfactory result obtained naturally for the case (Figure 8). Orthodontic follow-up was indicated, but the patient was not submitted for financial conditions.

Figure 8 - Twelve-year follow-up.

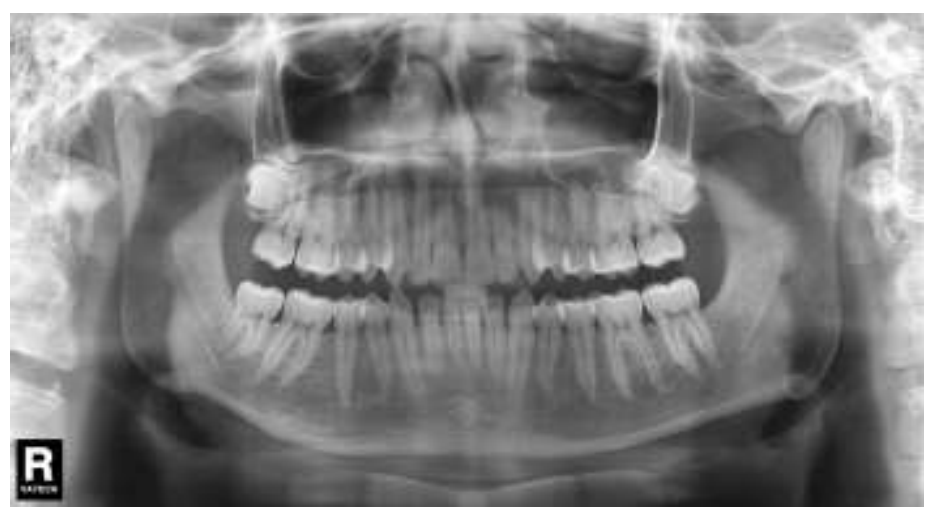

Source: Authors.

\section{Discussion}

Primary retention occurs more frequently in the permanent dentition (Biederman et al., 1962; McCartney et al., 1974; Raghoebar et al., 1989, 1991; Zengin et al., 2008). However, the prevalence rate of lower first molar impaction is low (0.01\% to $0.08 \%$ ) (Bereket et al., 2011; Dachi et al., 1961; Grover et al., 1985; Valmaseda-Castellón et al., 1999). The radiographic evaluation in the present study revealed a rare case of primary impaction of the permanent lower first molar.

The likely causes of an impacted lower first molar are not well known. Possible factors are categorized as local or 
systemic (Almonaitiene et al., 2010; Peterson et al., 2005; Proff et al., 2006). Local factors range from a dense bone lining, excess soft tissue or inadequate length of the dental arch (Peterson et al., 2005 to delayed maturation of the affected tooth, an enlarged crown, thickened follicle and dilacerated roots (Mellor et al., 1981; Nielsen et al., 2006). In three cases of impacted lower first molars, Mellor (1981) found accentuated curvature of the root apices in close contact with the lower edge of the mandible. As an atypical number of roots (4) were found in impacted molar in the case described herein, with accentuated curvature and in close contact with the lower edge of the mandible, these roots were likely the main etiological factors of impaction. Moreover, there was no evidence to suggest any other cause.

Molar impaction can cause problems regarding chewing performance and the stability of the dental arch. All methods for the repositioning of an impacted tooth should be considered prior to an invasive surgical approach. Due to the importance of the permanent first molars, the treatment of choice in cases of impaction is the surgical exposure of the tooth, followed by orthodontic traction (Anderson et al., 2012; Going et al., 1999; Ohaman et al., 1980). However, traction is not always possible and surgical repositioning (autotransplantation) is then indicated (Frank et al., 2000; Park et al., 2010; Sabuncuoglu et al., 2010; Schatz et al., 1994). When this method is also not viable due to the state of the impacted tooth, its occlusal relationship or inadequate space in the arch, extraction is indicated (Andreasen et al., 1990; Babacan et al., 2006; Bedoya et al., 2009; Frank et al., 2000; Going et al., 1999; Kokich et al., 1993; Ohaman et al., 1990; Sawicka et al., 2007; Schatz et al., 1994; Schwartz et al., 1985). In the case reported herein, extraction was performed due to the fact that the impacted tooth was in close contact with the lower edge of the mandible, thereby rendering other forms of treatment unviable.

The patient did not have access to sequential orthodontic treatment and abandoned treatment. Twelve years later, he returned to the dental service for extraction of the third upper molars, at which time we observed the natural repositioning of the second and third molars lower in place of the first molar lost and the satisfactory result obtained naturally for the case.

\section{Final Considerations}

We emphasize the importance of investigating extraoral volumetric increases. Extraoral volumetric increases are not always related to infectious conditions and need to be investigated. Asymptomatic cases such as the one reported need to be investigated for having possible relationships with included teeth, cysts and even tumors. We suggest further work to investigate the causes of primary first molar retention so that they can be prevented.

\section{References}

Almonaitiene, R., Balciuniene, I., \& Tutkuviene, J. (2010). Factors influencing permanent teeth eruption. Part one-general factors. Stomatologija, 12(3), 6772.

Anderson, K., Murtagh, K., \& Sacks, H. G. (2012). Soft tissue and occlusal management in the surgical uprighting of impacted molars. Journal of Oral and Maxillofacial Surgery, 70(8), e438-e440.

Andreasen, J. O., Paulsen, H. U., Yu, Z., \& Bayer, T. (1990). A long-term study of 370 autotransplanted premolars. Part IV. Root development subsequent to transplantation. European Journal of Orthodontics, 12, 38-50.

Bang, E., Kjær, I., \& Christensen, L. R. (1995). Etiologic aspects and orthodontic treatment of unilateral localized arrested tooth development combined with hearing loss. American Journal of Orthodontics and Dentofacial Orthopedics, 108(2), 154-161.

Babacan, H., Ay, S., \& KÖşger, H. H. (2006). Impacted permanent first molars: two case reports. International dental journal, 56(1), $49-54$.

Becktor, K. B., Bangstrup, M. I., Rølling, S., \& Kjær, I. (2002). Unilateral primary or secondary retention of permanent teeth, and dental malformations. The European Journal of Orthodontics, 24(2), 205-214.

Bjerklin, K., Kurol, J., \& Paulin, G. (1993). Ectopic eruption of the maxillary first permanent molars in children with cleft lip and/or palate. The European Journal of Orthodontics, 15(6), 535-540.

Bereket, C., Özkan, N., Sener, Ý., Kara, M. I., Aktan, A. M., \& Arici, N. (2011). Retrospective analysis of impacted first and second permanent molars in the Turkish population: A multicenter study. 
Bedoya, M. M., \& Park, J. H. (2009). A review of the diagnosis and management of impacted maxillary canines. The Journal of the American Dental Association, 140(12), 1485-1493.

Biederman, W. (1962). Etiology and treatment of tooth ankylosis. American Journal of Orthodontics, 48(9), 670-684.

Chintakanon, K., \& Boonpinon, P. (1998). Ectopic eruption of the first permanent molars: prevalence and etiologic factors. The Angle Orthodontist, 68(2), 153-160.

Dachi, S. F., \& Howell, F. V. (1961). A survey of 3,874 routine full-mouth radiographs: II. A study of impacted teeth. Oral Surgery, Oral Medicine, Oral Pathology, 14(10), 1165-1169.

da Silva Filho, O. G., De Albuquerque, M. V. P., \& Kurol, J. (1996). Ectopic eruption of maxillary first-permanent molars in children with cleft lip. The Angle Orthodontist, 66(5), 373-380.

De Freitas R, Marin JLS. Surgery of impacted tooth (2008). In: De Freitas R, eds. Treaty maxillofacial surgery. (2th ed.), Santos; $151-84$.

Frank, C. A. (2000). Treatment options for impacted teeth. The Journal of the American Dental Association, 131(5), 623-632.

Fujiyama, K., Yamashiro, T., Fukunaga, T., Balam, T. A., Zheng, L., \& Takano-Yamamoto, T. (2004). Denervation resulting in dento-alveolar ankylosis associated with decreased Malassez epithelium. Journal of dental research, 83(8), 625-629.

Going Jr, R. E., \& Reyes-Lois, D. B. (1999). Surgical exposure and bracketing technique for uprighting impacted mandibular second molars. Journal of oral and maxillofacial surgery, 57(2), 209-212.

Grover, P. S., \& Lorton, L. (1985). The incidence of unerupted permanent teeth and related clinical cases. Oral Surgery, Oral Medicine, Oral Pathology, 59(4), 420-425.

Kokich, V. G., \& Mathews, D. P. (1993). Surgical and orthodontic management of impacted teeth. Dental Clinics of North America, 37(2), 181-204.

Kurol, J., \& Bjerklin, K. (1982). Resorption of maxillary second primary molars caused by ectopic eruption of the maxillary first permanent molar: a longitudinal and histological study. ASDC journal of dentistry for children, 49(4), 273-279.

Marks Jr, S. C., \& Schroeder, H. E. (1996). Tooth eruption: theories and facts. The Anatomical Record: An Official Publication of the American Association of Anatomists, 245(2), 374-393.

Marzola C (1988). Dental Retention. In: Marzola C, eds. Dental Retention. (2th ed.), Pancast; 13-44.

McABOY, C. P., Grumet, J. T., Siegel, E. B., \& Iacopino, A. M. (2003). Surgical uprighting and repositioning of severely impacted mandibular second molars. The Journal of the American Dental Association, 134(11), 1459-1462.

McCartney, T. I. (1974). A submerging lower first permanent molar. Journal of dentistry, 2(6), 260-262.

Mellor, T. K. (1981). Six cases of non-eruption of the first adult lower molar tooth. Journal of dentistry, 9(1), 84-88.

Nielsen, S. H., Becktor, K. B., \& Kjær, I. (2006). Primary retention of first permanent mandibular molars in 29 subjects. The European Journal of Orthodontics, 28(6), 529-534.

Öhman, I., \& Öhman, A. (1980). The eruption tendency and changes of direction of impacted teeth following surgical exposure. Oral Surgery, Oral Medicine, Oral Pathology, 49(5), 383-389.

Oliver, R. G., Richmond, S., \& Hunter, B. (1986). Submerged permanent molars: four case reports. British Dental Journal, 160(4), 128-130.

Park, J. H., Tai, K., \& Hayashi, D. (2010). Tooth autotransplantation as a treatment option: a review. Journal of Clinical Pediatric Dentistry, 35(2), 129-135.

Parner, E. T., Heidmann, J. M., Kjaer, I., Vaeth, M., \& Poulsen, S. (2002). Biological interpretation of the correlation of emergence times of permanent teeth. Journal of Dental Research, 81(7), 451-454

Peterson LJ (2005). Principles of the treatment of impacted teeth. In: Peterson LJ, Ellis E, Hupp JR, Tucker MR, eds. Contemporary oral and maxillofacial surgery. 3th ed. São Paulo: Elsevier; 2005: 197-227.

Pomarico, L., Primo, L. G., \& Noce, D. (2006). Ectopic eruption of the maxillary central permanent incisors and mandibular first permanent molars: Report of an unusual case. Quintessence international, 37(9).

Proff, P., Bayerlein, T., Fanghänel, J., Allegrini Jr, S., \& Gedrange, T. (2006). Morphological and clinical considerations of first and second permanent molar eruption disorders. Annals of Anatomy-Anatomischer Anzeiger, 188(4), 353-361.

Raghoebar, G. M., Boering, G., Jansen, H. W. B., \& Vissink, A. (1989). Secondary retention of permanent molars: a histologic study. Journal of Oral Pathology \& Medicine, 18(8), 427-431.

Raghoebar, G. M., Boering, G., Vissink, A., \& Stegenga, B. (1991). Eruption disturbances of permanent molars: a review. Journal of oral pathology \& medicine, 20(4), 159-66.

Raghoebar, G. M., Boering, G., \& Vissink, A. (1991). Clinical, radiographic and histological characteristics of secondary retention of permanent molars. Journal of dentistry, 19(3), 164-170. 
Research, Society and Development, v. 10, n. 4, e24110413699, 2021

(CC BY 4.0) | ISSN 2525-3409 | DOI: http://dx.doi.org/10.33448/rsd-v10i4.13699

Sabuncuoglu, F. A., Sencimen, M., \& Gülses, A. (2010). Surgical repositioning of a severely impacted mandibular second molar. Quintessence International, 41(9).

Sawicka, M., Racka-Pilszak, B., \& Rosnowska-Mazurkiewicz, A. (2007). Uprighting partially impacted permanent second molars. The Angle Orthodontist, 77(1), 148-154.

Schatz, J. P., \& Joho, J. P. (1994). Indications of autotransplantation of teeth in orthodontic problem cases. American Journal of Orthodontics and Dentofacial Orthopedics, 106(4), 351-357.

Schwartz, O., Bergmann, P., \& Klausen, B. (1985). Autotransplantation of human teeth: a life-table analysis of prognostic factors. International journal of oral surgery, 14(3), 245-258.

Valmaseda-Castellón, E., De-la-Rosa-Gay, C., \& Gay-Escoda, C. (1999). Eruption disturbances of the first and second permanent molars: results of treatment in 43 cases. American journal of orthodontics and dentofacial orthopedics, 116(6), 651-658.

Watkins, J. J., \& Tucker, G. J. (1977). An unusual form of impaction of two permanent molars: a case report. Journal of dentistry, 5(3), 215-218.

Zengin, A. Z., Sumer, A. P., \& Karaarslan, E. (2008). Impacted primary tooth and tooth agenesis: a case report of monozygotic twins. European journal of dentistry, 2, 299. 